\title{
Review
}

\section{TNF $\alpha$ and Immune Checkpoint Inhibition: Friend or Foe for Lung Cancer?}

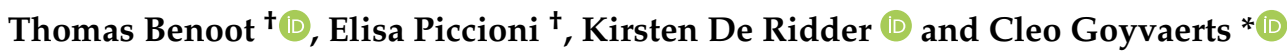 \\ Laboratory for Molecular and Cellular Therapy, Department Biomedical Science, Vrije Universiteit Brussel (VUB), \\ Laarbeeklaan 103, 1090 Brussels, Belgium; thomas.benoot@vub.be (T.B.); \\ piccioni.1750442@studenti.uniroma1.it (E.P.); kirsten.de.ridder@vub.be (K.D.R.) \\ * Correspondence: cleo.goyvaerts@vub.be \\ + Both authors contributed equally to this review.
}

Citation: Benoot, T.; Piccioni, E.; De Ridder, K.; Goyvaerts, C. TNF $\alpha$ and Immune Checkpoint Inhibition: Friend or Foe for Lung Cancer? Int. J. Mol. Sci. 2021, 22, 8691. https:// doi.org/10.3390/ijms22168691

Academic Editor: Silvie Rimpelova

Received: 15 July 2021

Accepted: 11 August 2021

Published: 13 August 2021

Publisher's Note: MDPI stays neutral with regard to jurisdictional claims in published maps and institutional affiliations.

Copyright: (c) 2021 by the authors. Licensee MDPI, Basel, Switzerland. This article is an open access article distributed under the terms and conditions of the Creative Commons Attribution (CC BY) license (https:/ / creativecommons.org/licenses/by/ $4.0 /)$.

\begin{abstract}
Tumor necrosis factor-alpha $(\mathrm{TNF} \alpha)$ can bind two distinct receptors (TNFR1/2). The transmembrane form $(\operatorname{tmTNF} \alpha)$ preferentially binds to TNFR2. Upon tmTNF $\alpha$ cleavage by the TNF-alpha-converting enzyme (TACE), its soluble (sTNF $\alpha$ ) form is released with higher affinity for TNFR1. This assortment empowers TNF $\alpha$ with a plethora of opposing roles in the processes of tumor cell survival (and apoptosis) and anti-tumor immune stimulation (and suppression), in addition to angiogenesis and metastases. Its functions and biomarker potential to predict cancer progression and response to immunotherapy are reviewed here, with a focus on lung cancer. By mining existing sequencing data, we further demonstrate that the expression levels of TNF and TACE are significantly decreased in lung adenocarcinoma patients, while the TNFR1/TNFR2 balance are increased. We conclude that the biomarker potential of TNF $\alpha$ alone will most likely not provide conclusive findings, but that TACE could have a key role along with the delicate balance of $\operatorname{sTNF} \alpha / \operatorname{tmTNF} \alpha$ as well as TNFR1/TNFR2, hence stressing the importance of more research into the potential of rationalized treatments that combine $\mathrm{TNF} \alpha$ pathway modulators with immunotherapy for lung cancer patients.
\end{abstract}

Keywords: TNF $\alpha$; TNFR1; TNFR2; lung cancer; immunotherapy; immune checkpoint inhibition (Min. 5-Max. 8)

\section{The Pleiotropic Immunological Biology of TNF $\alpha$}

About 60 years ago, it was reported that bacterial endotoxin administration to mice resulted in the release of a serological protein with necrotic anti-tumor activity at high concentrations. Due to the latter characteristic, this protein was termed tumor necrosis factor (TNF) [1] and considered a breakthrough for cancer therapy. Today, the TNF superfamily consists of 19 members and 29 TNF receptors [2]. Within this family, functional $\mathrm{TNF} \alpha$ is represented by a trimer of $17.35 \mathrm{kDa}$ monomers, folded into a rigid bell-shaped "jelly roll" composed of antiparallel filaments [3]. It exists in two forms: a transmembrane form $(\operatorname{tmTNF} \alpha)$ next to a soluble $(\operatorname{sTNF} \alpha)$ form. The latter one is cleaved from tmTNF $\alpha$ by the metalloproteinase TNF-alpha-converting enzyme (TACE). Upon X-ray crystallography analysis, TNF $\alpha$ was demonstrated to bind to TNF receptors 1 and 2 (TNFR1 and TNFR2), represented by a 55 and $75 \mathrm{kDa}$ type I and type II transmembrane protein, respectively [4,5]. The structural pleiotropism of TNF $\alpha$ and its receptors endows it with a multifaceted role linked to both anti- and pro-inflammatory assets as well as apoptotic assets. The complexity of these findings tempered the original enthusiasm for $\mathrm{TNF} \alpha$ as a breakthrough molecule for cancer therapy.

\subsection{The Pro-Inflammatory Character of sTNF $\alpha$ versus tmTNF $\alpha$}

Soluble TNF $\alpha$ is mainly secreted by activated macrophages [6] and to a lesser extent, by T lymphocytes, natural killer (NK) cells, neutrophils, endothelial and cardiac muscle cells, fibroblasts, and osteoclasts $[7,8]$. By comparison, $\operatorname{tmTNF} \alpha$ is expressed constitutively on the 
surface of a broad range of immune cells such as alveolar and non-alveolar macrophages [9], monocytes [10], lymphocytes [11], dendritic cells (DCs), and NK cells [12]. In addition, its expression has been reported on non-immune cells such as adipocytes [13] and tumor cells [14].

In general, sTNF $\alpha$ is rapidly released upon trauma or infection, as it is bestowed with a determining role in immunoregulatory processes such as immune ontogeny, inflammation, and apoptosis [7]. As a soluble pro-inflammatory cytokine, it primarily acts at sites remote from the TNF $\alpha$-producing cells to support the production of downstream pro-inflammatory cytokines along with the recruitment, activation, and regulation of inflammatory cells such as macrophages. To illustrate, when macrophages are activated by Toll-like receptors, they secrete $\operatorname{sTNF} \alpha$, which subsequently regulates macrophage differentiation in an autocrine fashion [15]. Hence, TNF $\alpha$ neutralizing antibodies have been shown to reduce the production of several pro-inflammatory cytokines and growth factors such as interleukin-1 (IL-1) and granulocyte-macrophage colony-stimulating factor (GM-CSF) [16]. Of note, sTNF $\alpha$ has an intrinsic pleiotropic activity as it is also involved in anti-inflammatory responses that aim to restore homeostasis [17].

In comparison, tmTNF $\alpha$ is an important mediator of immune-cell crosstalk. To illustrate, when DCs express tmTNF $\alpha$, the latter can interact with TNFR2 on NK cells, resulting in increased NK cell proliferation and cytotoxic activity [18]. Moreover, tmTNF $\alpha$ can act in a dual manner upon its interaction with TNFR: either as a ligand or as a receptor through an "outside-to-inside" signaling pathway known as "reverse signaling". There is evidence that, as a ligand, it is mainly involved in host defense mechanisms against infections [19], while the receptor-like form appears to have a role in modulating immune cell activation. To elaborate, tmTNF $\alpha$ expressed by activated T cells can bind to TNFR2, expressed by monocytes, leading to monocyte activation with subsequent secretion of interleukin-10 (IL-10) and STNF $\alpha$. Additionally, endogenous IL-10 was shown to downregulate T cell contact-mediated sTNF $\alpha$ production by monocytes, suggestive for an autoregulatory loop involving both STNF $\alpha$ and tmTNF $\alpha$ [19-21]. What is more, T cells can also activate monocytes by expressing TNFR2 that can trigger reverse signaling via tmTNF $\alpha$, expressed by the monocytes. Hence, both TNF $\alpha$ isoforms are significantly involved in the regulation of the inflammatory response [22].

\subsection{Two Distinct Receptors Fine-Tune TNF $\alpha$ 's Biological Effects}

TNFR1, also known as tumor necrosis factor receptor superfamily, member 1A (TNFRSF1A) or CD120a, is expressed on almost all host cells including various tumor cell types [23-26] and tumor-associated endothelial cells [27]. In contrast, TNFR2 (TNFRSF1B or CD120b) is predominantly located on the surface of immune cells, such as NK cells, macrophages [28], regulatory T cells (Tregs), suppressive myeloid cells [29], and endothelial cells [30]. As indicated by "+" in Figure 1, sTNF $\alpha$ shows a significantly higher affinity for TNFR1 than $\operatorname{tmTNF} \alpha$, while the opposite holds true for TNFR2 [31,32].

In terms of biological effects, high affinity binding to TNFR1 (and not TNFR2) has been demonstrated to result in DC activation and subsequent stimulation of antigen specific $\mathrm{CD}^{+} \mathrm{T}$ cells [33]. That TNFR1-knockout (ko) mice show resistance to colitis development [34] further confirms its involvement in the differentiation of inflammatory $\mathrm{T}$ cells. In comparison, activation of TNFR2 in lymphoid cells leads to inflammatory responses as well as T cell activation, thymocyte proliferation, GM-CSF production [7], and NK cell-mediated IFN- $\gamma$ production [35]. Yet, its main role seems to be linked to restoration of homeostasis and promotion of an immunosuppressive environment, as TNFR2 gene ko models show elevated inflammatory responses [33,34,36]. To illustrate, TNFR2 signaling has been shown to promote Treg differentiation, proliferation, and suppressive function, while TNFR1 does not affect Treg cell expansion [37-39]. Moreover, upon activation of both TNFRs, TNFR2 is more liable to receptor shedding than TNFR1 [40-42]. The shedded soluble TNFRs have been shown to serve as decoy receptors for sTNF $\alpha$ to control its innate immune activation threshold. Hence, more pronounced TNFR2 shedding is in line with its immune restorative function $[43,44]$. 
Next to their roles in immune cell proliferation and activation, triggered TNFR1 and TNFR2 can also induce apoptotic and necrotic cell death. In the case of TNFR1, this is the result of the interaction between the receptors' death domain (DD) and the adapter protein TNF receptor-associated death domain (TRADD). Upon interaction of DD-TRADD, the activation of cysteine-aspartyl-specific proteases (caspases) is stimulated $[45,46]$. Although TNFR2 lacks a DD, it has been reported to cause activation-induced cell death (AICD), e.g., in mature $\mathrm{CD} 8^{+} \mathrm{T}$ cells [36]. As outlined in Figure 1, the different outcomes upon TNFR1 and 2 triggering result from their distinct downstream signaling [47]. Although both exploit the NF- $\mathrm{KB}$ pathway for transcriptional activation of inflammatory and anti-apoptotic genes [48], the "classical" NF- $\mathrm{BB}$ pathway is mainly activated upon STNF $\alpha$ binding to TNFR1 [31], while the "alternative pathway" is preferentially but not exclusively primed upon TNFR2 binding $[28,49,50]$. Additionally, both TNFRs can regulate gene expression by activating at least two members of the MAP kinase (MAPK) family, such as P38 [51,52] and JNK [53], and this via a series of protein phosphorylations (MEKK). Notably, the TNF superfamily member lymphotoxin alpha can, in its soluble homotrimer form (LT $\alpha 3)$, also bind to both TNFRs with an affinity profile comparable to that of sTNF $\alpha[54,55]$. In terms of biological effects, sTNF $\alpha$ and LT $\alpha 3$ have been reported to show equal mitogenic stimulation capacities upon TNFR binding, yet sTNF $\alpha$ was shown to be more potent to mediate gene regulation and cytotoxicity.

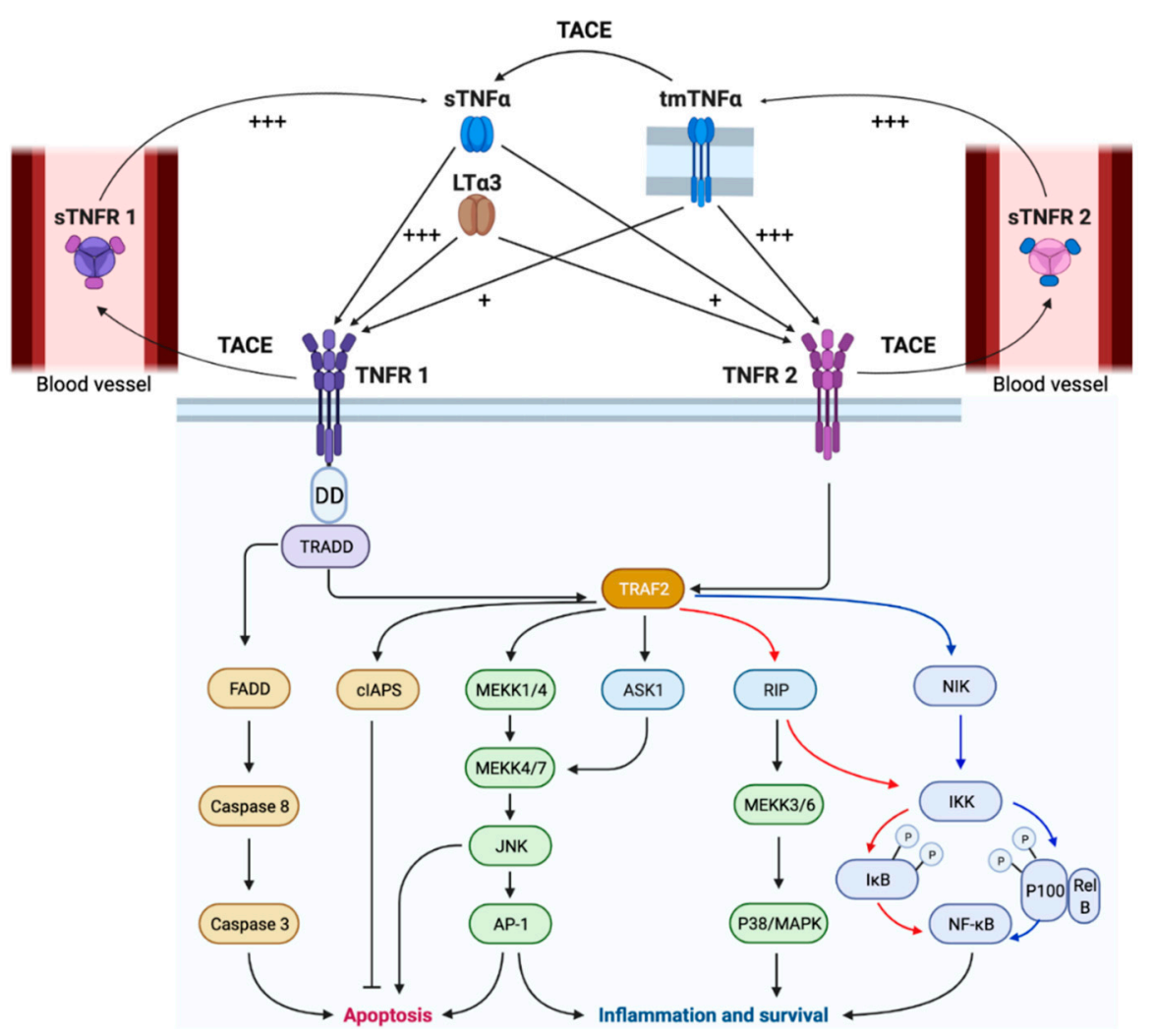

Figure 1. Pathways activated by soluble TNF $\alpha(\operatorname{sTNF} \alpha)$ and transmembrane $\operatorname{TNF} \alpha(\operatorname{tmTNF} \alpha)$ upon binding to TNFRs. Downstream signaling via TNFR1 is most effective upon high-affinity $(+++)$ binding to $\operatorname{TNNF} \alpha$. In the case of TNFR1, this can lead to caspase8/3-mediated apoptosis through signaling via its death domain (DD), recruitment of TRADD, and subsequent recruitment of FADD or TRAF2. The latter could also result in activation of pro-inflammatory signals via the "classical NF- $\kappa B$ " pathway, and is primarily activated via TNFR1 (red arrows). Upon high-affinity (+++) binding of tmTNF $\alpha$ to TNFR2, TRAF2 is triggered, which preferentially results in NF- $\mathrm{BB}$ activation via the alternative pathway (blue arrows) to activate the expression of proliferation and survival related genes. 
Both $\operatorname{sTNF} \alpha$ and tmTNF $\alpha$ bind with low-affinity (+) to TNFR2 and TNFR1 respectively. TNFalpha-converting enzyme (TACE), responsible for the conversion of sTNF $\alpha$ from tmTNF $\alpha$ and of soluble TNFRs [56]. For completeness, the alternative TNFR ligand lymphotoxin alpha 3 (LT $\alpha 3$ ), with its affinity binding profile to TNFR1 and 2, is depicted as well. This figure was created with BioRender.com (accessed on 4 June 2021).

In conclusion, the presence of two functional isoforms (soluble and transmembrane) next to two receptors with specific expression, affinity, and downstream signaling avenues collectively serves the pleiotropic job description of TNF $\alpha$. As regulator of cytotoxic, pro-, and anti-inflammatory functions, it is evident that TNF $\alpha$ can play a critical role in the development of chronic inflammatory diseases as well as cancer, as outlined below.

\section{TNF $\alpha$ Plays Opposing Roles in Cancer}

Despite TNF $\alpha$ 's denomination, in vitro reported tumor necrosis after high TNF $\alpha$ concentrations appeared a phenomenon that is not so straightforwardly translated to successful cancer treatments in vivo. The latter is partly explained by TNF $\alpha^{\prime}$ s multifunctionality as a cytotoxic but also immune modulating cytokine. As the immune system plays a complex role on the tumor microenvironmental (TME) battlefield, TNF $\alpha$ is used as a weapon to modulate and/or kill tumor cells, immune cells, and/or endothelial cells [57].

Previously observed direct anti-tumoral properties of TNF $\alpha$ in vivo are among others based on its capacity to hinder tumor-associated blood vessel formation (angiogenesis) via selective endothelial cytotoxicity and necrotic hemorrhage [58]. This selective endothelial cytotoxicity can subsequently result in hyperpermeability of tumor vessels and increased blood cell extravasation. The exact underlying mechanism remains unknown, yet van Horssen et al. [59] described the noteworthy hypothesis that tumor-residing endothelial cells are more sensitive to TNF $\alpha$ because they upregulate TNFR1 upon cytokine signaling by tumor cells and macrophages. However, external administration of TNF $\alpha$ was shown to occupy TNFR1 expressed by tumor and healthy endothelial cells without toxicity towards the latter, due to the presence of a low number of receptors on healthy cells [60]. Nevertheless, studies in mice and rats further showed a synergistic anti-tumor effect of $\mathrm{TNF} \alpha$ in combination with chemotherapeutic drugs, as accumulation of the latter at the tumor site was shown to be improved [61-63]. Moreover, persistent high-level stimulation with TNF $\alpha$ in vitro inhibits endothelial cell proliferation in a dose-dependent manner [64], further supporting its anti-angiogenic effects [65-67]. However, Fajardo et al. hypothesized that TNF $\alpha$ could show both pro- and anti-angiogenic effects in vivo, depending on its local concentration. When murine TNF $\alpha$ was administered subcutaneously in mice, this was shown to exert opposing effects. At low doses (range: $0.01-1 \mathrm{ng}$ ), TNF $\alpha$ induced angiogenesis whereas increasing doses $(1$ and $5 \mu \mathrm{g})$ reduced this effect with complete abolishment at the highest doses [68].

While a high concentration of TNF $\alpha$ has been linked to hemorrhagic necrosis, it is now widely accepted that chronic exposure to TNF $\alpha$ is more likely to promote tumor progression. First, it has been demonstrated repeatedly that chronic inflammation, in which the innate immune system plays a leading role, can promote cancer onset as well as progression and metastasis, typifying the "never-healing-wound" character of solid cancers $[69,70]$. Indeed, chronic exposure to $\mathrm{TNF} \alpha$ can promote cellular transformation via the induction of direct mutations and DNA damage [71] as well as via profound epigenetic changes that modulate the expression level of oncogenes and tumor suppressor genes [72]. In addition, inflammation influences epithelial-to-mesenchymal cell transition (EMT) and subsequent cancer cell invasion. Further, TNF $\alpha$ has been shown to affect expression of EMT-inducing transcription factors, particularly in synergy with TGF $\beta$ [73]. Moreover, TNF $\alpha$ associated with chronic inflammation can be held responsible for the observed phenomenon of cancer cell specific resistance to TNF $\alpha$-induced cell death [74]. Specifically, chronic TNF $\alpha /$ TNFR1 binding increases the expression of anti-apoptotic, angiogenic, and invasive proteins via the TAK-1, MAPKs, Akt, IKK, AP-1, and NF-KB signaling pathways [28,75,76]. Notably, also 
the ligands and receptors of the LT $\alpha$ family with, among others, affinity for TNFR1 and 2, have been linked to increased carcinogenesis, as extensively reviewed elsewhere [55,77].

Even if chronic inflammation is not involved in the onset of tumor cell transformation, the immune system often becomes a co-worker during cancer progression. Today it is generally accepted that the immune system can identify and control nascent malignancies in a process called cancer immunosurveillance. In contrast, the latter can also promote tumor progression through the selection of poorly immunogenic variants and suppression of anti-tumor immunity. Together, the dual host-protective and tumor-promoting actions of immunity are referred to as cancer immunoediting and comprise three distinct phases: the elimination, equilibrium, and escape phase [78-80].

The elimination phase is characterized by an imbalance towards more anti-tumor immunity, installed by adaptive as well as innate immune cells. Characteristic for a potent Th1-oriented tumor-associated antigen (TAA) specific adaptive immune response is the presence of immunogenic TAAs, presented via MHC-I on the surface of tumor cells, together with Fas, TRAIL, and IFN- $\gamma$ receptors and the presence of perforin, granzymes, IFN- $\alpha / \beta / \gamma$, IL-1, IL-12, and TNF $\alpha$ within the TME. Hence, TNF $\alpha$ can ameliorate this phase through its involvement in activation of T cells, macrophages, and NK cells. For example, it was shown that TNFR1 signaling promotes the accumulation of anti-tumor M1 polarized tumor-associated macrophages (TAMs) by suppressing the M2-polarizing release of IL-13 from eosinophils co-recruited with inflammatory monocytes [81]. On their turn, MHC-II high (M1) TAMs and granulocytes can secrete, among others, TNF $\alpha$, IL- 1 , and IL-12 to further ameliorate a Th1-polarized anti-tumor immune profile [82].

During the equilibrium phase, anti- and pro-tumor immunity are in balance and/or immune-mediated tumor dormancy is installed [80]. It was reported that the absence of TNFR or IFN- $\gamma$ promoted angiogenesis and multistage carcinogenesis in an experimentally induced pancreatic murine tumor model, suggesting that a coordinated interaction between IFN- $\gamma$ and TNF $\alpha$ was responsible for the activation of TAA-specific cytotoxic T cells [83]. Moreover, the combination of IFN- $\gamma$ and TNF $\alpha$ drove pancreatic tumor cells into STAT- 1 and TNFR1-mediated senescence [82]. Because IFN- $\gamma$ and TNF $\alpha$ induce senescence in numerous murine and human cancers, this may be a general mechanism for arresting cancer progression.

In the escape phase, $\mathrm{TNF} \alpha$ has several effects capable of lowering the antitumor immune response by facilitating the accumulation and/or activation of a wide range of immunosuppressive cells such as Tregs [37], regulatory B cells [84], and suppressive myeloid cells [85]. As stated before, the common factor of these immunosuppressive effects lies within TNF $\alpha$ binding to TNFR2. When secreted by activated CD4 ${ }^{+}$T-cells, TNF $\alpha$ has been shown to induce myelopoiesis in tumor-bearing mice. Furthermore, cells of the myeloid lineage can be recruited to become immune-suppressive regulatory myeloid cells, which decrease TAA-specific $\mathrm{CD}^{+} \mathrm{T}$ cell mediated tumor cytotoxicity [86]. Moreover, it has been reported that $\operatorname{tmTNF} \alpha$, rather than $\operatorname{sTNF} \alpha$, is able to activate immunosuppressive myeloid cells upon binding to TNFR2. To illustrate, a marked increase in immunosuppressive myeloid cell accumulation was only observed when tmTNF $\alpha$ was constitutively expressed on 4T1 mammary tumor cells, with subsequent promotion of NO, ROS, IL-10, and TGF- $\beta$ secretion by these myeloid cells and inhibition of lymphocyte proliferation. In contrast, $4 \mathrm{~T} 1$ overexpression of $\mathrm{sTNF} \alpha$ resulted in increased lymphocyte infiltration and tumor regression [87]. TNF $\alpha$ also facilitates the installment of an effector $\mathrm{T}$ cell hostile milieu via indoleamine 2,3-dioxygenase 1 (IDO1) accumulation in the TME. To illustrate, while $\mathrm{M} 2 \mathrm{~b}$ polarized macrophage conditioned medium stimulates tumor cell proliferation and IDO1 expression in vitro, this is reduced upon TNF $\alpha$ neutralization [88]. As IDO1 converts tryptophan into kynurenine, tryptophan is deprived with subsequent installment of TAA-specific T cell anergy, while Treg activity, lymphangiogenesis, and neovascularization are enhanced in vivo. Finally, TNF $\alpha$ has been linked to cancer therapy resistance. To illustrate, in a murine triple-negative breast cancer model, resistance to the anti-angiogenic drug bevacizumab was shown to be accompanied by M2b TAM-mediated secretion of 
the chemokine CCL1 along with TNF $\alpha$. Upon TNF $\alpha$-neutralizing nanobody administration in vivo, this immunosuppressive M2b macrophage-induced resistance was overcome, supporting $\mathrm{TNF} \alpha$ 's key role in resistance to bevacizumab [88].

Although both TNF $\alpha$ and its receptors' precise role within the complex and everevolving TME are far from fully understood, substantial evidence has emerged that TNF $\alpha$ signaling has a paradoxical and dual role in cancer progression and the dynamic immunoediting process. While it has been held responsible for key tumor promoting features such as the maintenance of an antigen-ignorant chronic inflammatory state and immunosuppressive effects that hinder TAA-specific effector functions, its documented anti-tumor assets in vitro and in vivo hamper a clear-cut conclusion.

\section{Specificities of TNF $\alpha$ in Lung Cancer Progression}

Lung cancer remains the leading cause of cancer-related deaths worldwide, responsible for almost 1.8 million deaths in 2020 alone [89]. Lung cancer comprises two key types: non-small cell lung cancer (NSCLC), accounting for $80-85 \%$ of cases, and small cell lung cancer (SCLC) [90].

As the human respiratory tract is continuously exposed to air that can potentially contain airborne pathogens, lungs necessitate a unique, fine-tuned, and rapidly acting pulmonary immune system to maintain homeostasis [91]. When the immunohistological expression of TNF $\alpha$ and its receptors was evaluated in healthy human lung tissue, TNF $\alpha$ was shown to be particularly prominent in bronchial epithelial cells, vascular smooth muscle cells, and alveolar macrophages. In addition, TNFR1 was shown to be eminently expressed on bronchial epithelial cells and endothelial cells, while TNFR2 was expressed by nearly all cell types [92]. Therefore, it is not surprising that in the complex process of lung cancer onset, progression, and dissemination, $\mathrm{TNF} \alpha$ and its receptors have been reported to play decisive roles, too. Indeed, it was recently described that TNF is one of the co-occurring frequently altered immune genes found within the TCGA pan-cancer lung adenocarcinoma (LUAD) dataset $(n=507)$ [93]. However, the exact effect seems to be nuanced by contradicting functions governed by their isoforms, signal strength, and downstream signaling pathways. This is illustrated by the finding that specific genetic polymorphisms of the TNF gene region impact lung cancer progression differently. While the $238 \mathrm{G}>$ A polymorphism, found in the promoter region of $\mathrm{TNF} \alpha$, has a favorable prognostic association for NSCLC [94], the $308 \mathrm{G}>$ A polymorphism constitutes an increased risk for lung cancer [95].

Another opposing effect is found for $\operatorname{sTNF} \alpha$ and tmTNF $\alpha$ on lung cancer growth [96]. When murine lung tumor lines expressed $\operatorname{tmTNF} \alpha$, their engraftment resulted in the formation of small tumors with reduced tumor-associated myeloid cell infiltration, in contrast to control or sTNF $\alpha$-overexpressing lines. The observed myeloid cell reduction was found to be a direct effect of tmTNF $\alpha$ on myeloid survival via induction of ROS-mediated cell necrosis. Furthermore, human NSCLC was shown to express varying levels of sTNF $\alpha$ and $\operatorname{tmTNF} \alpha$, and gene expression patterns favoring $\operatorname{tmTNF} \alpha$ appeared predictive of improved lung cancer survival [96]. This is in contrast with previous findings using the mammary 4T1 model and, moreover, counterintuitive, as tmTNF $\alpha$ shows a higher affinity than sTNF $\alpha$ for the immunosuppression promoting TNFR2 [87]. The fact that TNF $\alpha$ could have a favorable impact on survival is further supported by a study on citronellol's ability to induce necroptosis of human lung tumor cells in vitro and in vivo. This study identified a decisive role for TNF $\alpha$ in this necroptosis induction via its activation of RIP1/3 and simultaneous downregulation of caspase $3 / 8$ activity [97].

In an attempt to predict the most common interactions between the different TNF $\alpha$ signaling members within the lung TME, we compared the overall TNF, TACE, TNFR1, and TNFR2 expression profiles within a healthy tissue and TCGA pan-cancer LUAD transcriptomic data set. We found a significant reduction of TNF, TACE, and TNFR2 transcripts within the LUAD cohort (Figure 2A,B), leading to an increased TNFR1/TNFR2 ratio (Figure $2 \mathrm{C}$ ). These findings imply that $\mathrm{LUAD}$ tumors are characterized by reduced 
numbers of TNF $\alpha$ and especially of sTNF $\alpha$ molecules as TACE is significantly reduced. The specific reduction of TNFR2 and not TNFR1 in LUAD tumors further implies that TNFR1 but not TNFR2 plays a crucial role in tumor progression. As TNFR1 also shows high affinity for LT $\alpha 3$, we used the same LUAD cohort to evaluate the expression profile of the lymphotoxin alpha monomer encoding gene $L T A$. We found a significant upregulation of LTA in the LUAD cohort compared to healthy controls (Figure 2D). Previous studies linked the expression of at least two LTA-signaling members to a poor clinical outcome in lung cancer patients: the receptor for the heterotrimeric LT $\alpha \beta(\mathrm{LT} \beta R)$ and the alternative LT $\alpha 3$ receptor herpes virus entry mediator (HVEM) $[98,99]$. Overall, these findings suggest that the TNF $\alpha$ pathway will have the highest likelihood to signal within the LUAD TME via TNFR1 through low-affinity binding to tmTNF $\alpha$ or high-affinity binding to LT $\alpha 3$, as graphically visualized with green arrows in Figure 3.
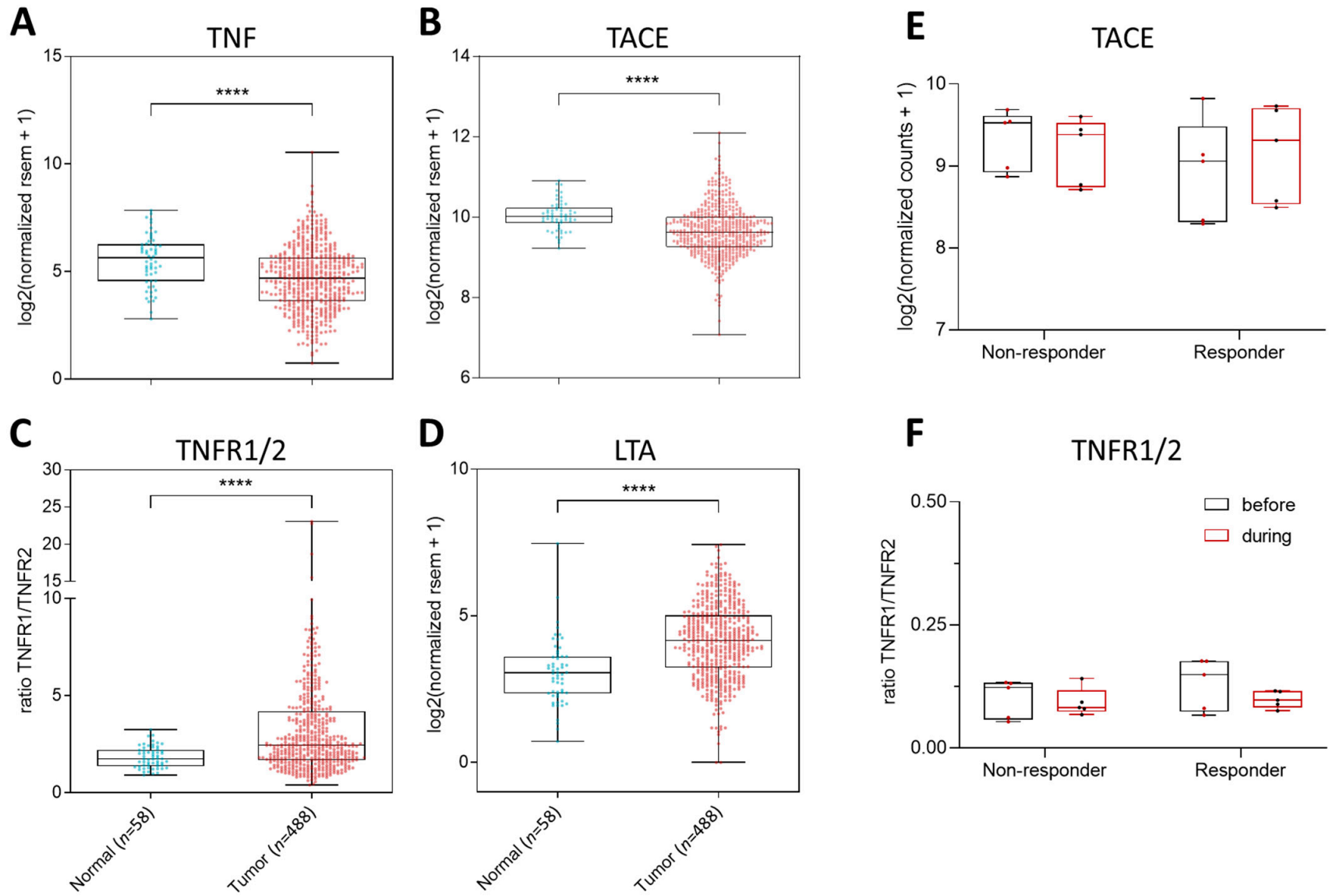

Figure 2. Gene expression analysis of several TNF family members within lung cancer patients. (A-D) Expression profiles were collected from TCGA for both normal $(n=58)$ and LUAD tumor tissue $(n=488)$. Next, we obtained the Log2transformed normalized RSEM values via Wanderer for TNF (A), TACE (B), TNFR1 and 2 (C), and LTA (D) [100]. For (C), the ratio of the expression values of TNFR1 over TNFR2 is depicted. Statistical analysis was performed using the Mann-Whitney test $\left.{ }^{* * * *}, p<0.0001\right)$. (E,F) Gene expression analysis of TACE, TNFR1, and TNFR2 in CD8 ${ }^{+}$T cells from NSCLC patients before and during anti-PD-1 mAb treatment. RNAseq dataset obtained from the Gene Expression Omnibus (GEO) database (accession number: GSE111414, accessed on 06/07/2021). Counts were normalized using DESeq2 in R. Counts for TNF were zero for most samples (data not shown). (A) Gene expression profile of TACE in both non-responder and responder groups. (B) Ratio of TNFR1 and TNFR2 normalized expression values. For each group: $n=5$. 


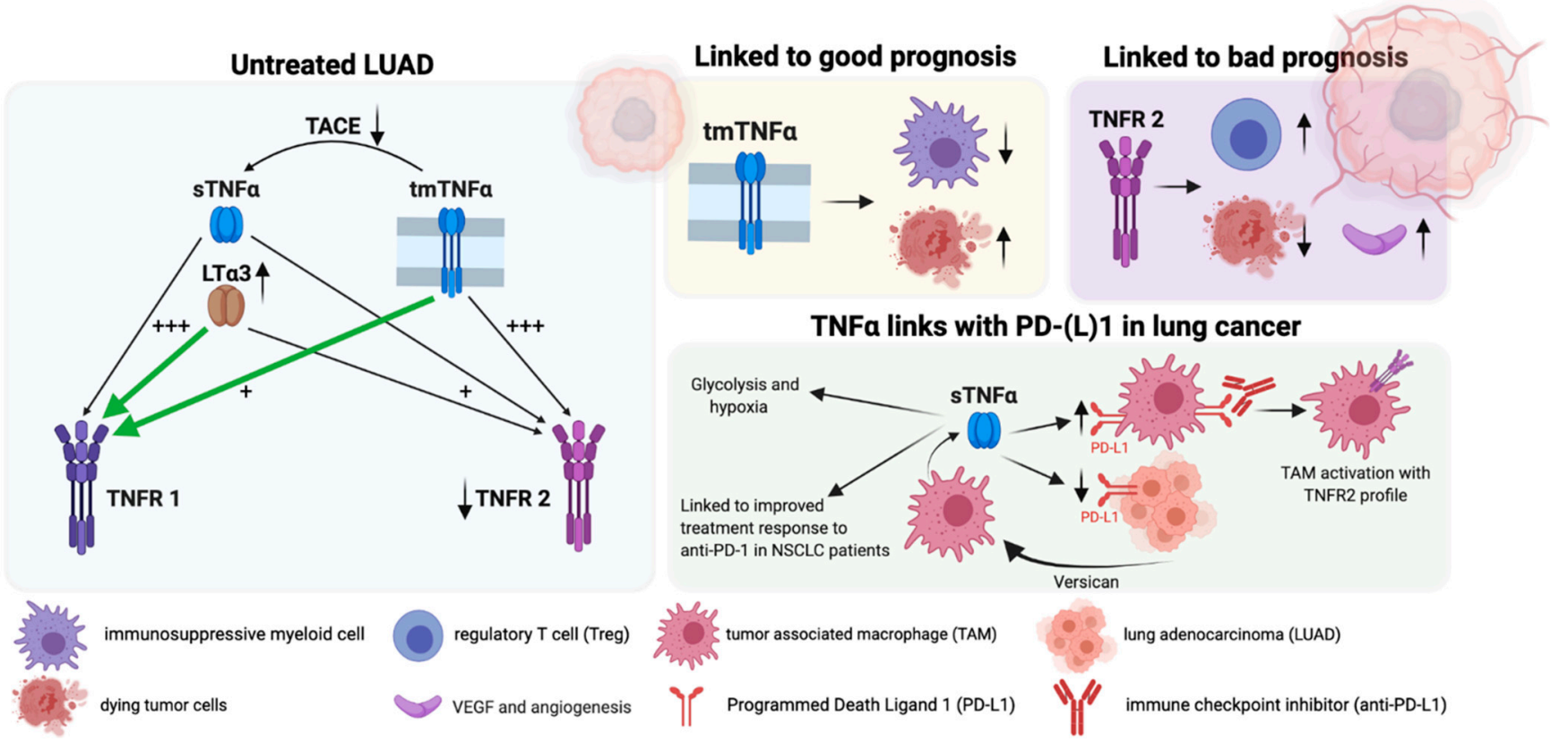

Figure 3. Overview of TNF $\alpha$ signaling within LUAD with link to prognosis and checkpoint inhibition. (+++) high-affinity binding, (+) low-affinity binding, green arrows support likeliness of TNF $\alpha$-signaling pathways in LUAD patients. This figure was created with BioRender.com (accessed on 5 August 2021).

Nevertheless, studies on the lung tumor growth promoting role of TNF $\alpha$ signaling are ample, too. First, several clinical studies have reported on the decisive role of TNF $\alpha$ in lung cancer EMT, invasion, and metastasis [101,102]. Secondly, TNF $\alpha$ has been shown to play an essential role in creating an immunosuppressive lung TME [103], among others, by upregulating MHC-II in alveolar type-II (AT-II) cells responsible for a plethora of functions that support the maintenance and optimal functioning of alveoli. Because AT-II cells' primary function is not antigen presentation, they lack co-stimulatory signals (CD80/CD86), essential to effectively prime $\mathrm{CD} 4^{+} \mathrm{T}$ cells. Thus, instead of creating an antitumor immune response, increased AT-II cell-specific MHC-II expression can trigger Treg differentiation [104]. Numerous studies evaluated TNFR2 as a potential biomarker for NSCLC as it has been shown to be crucial for TNF $\alpha$-mediated immunosuppression $[105,106]$. High amounts of TNFR2 ${ }^{+}$Tregs have been found in the TME of murine $[39,107]$ as well as human advanced lung cancers $[108,109]$, suggesting that Tregs are activated through TNF $\alpha /$ TNFR2 signaling. In addition, TNFR2 expression by lung tumor cells and the lung TME has been shown to support tumor cell survival [110], pre- metastatic niche formation [111], and neovascularization via vascular endothelial growth factor (VEGF) release. These findings are further supported by the observation that the levels of TNFR2 expression in human lung cancer patients, which are up to $35 \%$ [106], correlate positively to a more advanced clinical stage, immune invasion, progressive metastasis, shorter survival time, and poor prognosis $[106,108]$. These findings were confirmed in TNFR2-ko mice engrafted with the Lewis lung carcinoma (LLC) model. Compared to wild type and TNFR1/2 double ko mice, tumor growth decreased twofold in TNFR2-ko mice specifically and correlated with reduced VEGF expression and capillary density, along with increased numbers of apoptotic LLC cells. As they further showed that blocking TNFR2 via a short-hairpin RNA in cultured LLCs increased TNF $\alpha$-mediated apoptosis and expression of several angiogenic factors, they confirmed that TNFR2 directly ameliorates angiogenesis and LLC survival [110]. Moreover, Chopra et al. reported that TNF $\alpha$ or TNFR2 deficiency on immune cells resulted in the reduction of lung metastasis and a decrease in the number of pulmonary Tregs [39].

In conclusion, preclinical evidence suggests that TNFR2 is involved in lung tumor progression while tmTNF $\alpha$ (with high affinity for TNFR2) has been linked to a better 
prognosis for lung cancer patients. This implies that the biomarker potential of tmTNF $\alpha$ and TNFR2 for lung cancer progression most likely pivots on the delicate balances of sTNF $\alpha$ over tmTNF $\alpha$ as well as TNFR1 over TNFR2.

\section{Linking TNF $\alpha$ to Antitumor Immunotherapy in Lung Cancer}

The goal of antitumor immunotherapy is to completely and specifically eradicate both primary and metastatic tumor lesions by mobilized cytotoxic effector cells. Hence, immunotherapy can achieve actual cures of advanced lung cancer patients, representing an unprecedented reality $[112,113]$. Therefore, the first FDA approval of an immunotherapeutic treatment for squamous cell NSCLC benchmarked a revolutionary era for lung cancer patients. This treatment is based on blocking the immune checkpoint programmed death-1 (PD-1) pathway. Under healthy conditions this pathway is used to put an adequate brake on $\mathrm{T}$ cell stimulation and return to homeostatic conditions. As tumor cells can express the PD-1 ligand (PD-L1) themselves, they can corrupt this pathway to hinder their execution by PD-1+ TAA-specific cytotoxic effector cells [114,115]. Since 2016, five PD-(L)1 inhibitors (nivolumab, pembrolizumab, atezolizumab, durvalumab, and cemiplimab) have been approved by the FDA as second- and/or first-line treatment options for advanced NSCLC [93]. Notably, for the treatment of SCLC, both nivolumab and pembrolizumab were originally approved [116] yet have been withdrawn from the US market since confirmatory trials failed to evidence improved survival outcomes. Additionally, only $\sim 20 \%$ of unselected NSCLC patients benefit from blocking immune checkpoints, and many of the initial responders eventually develop resistance to therapy. Moreover, the growing trend to combine several immune checkpoint inhibitors (ICIs) coincides with a growing occurrence of severe to fatal immune-related adverse effects (irAEs), often related to a local increase in TNF $\alpha$ [117]. Together with the emerging concept of hyperprogression upon ICI [118], these phenomena cast light on the current knowledge gap of immunotherapy hampering mechanisms.

In search for clues, the relationship between TNF $\alpha$ and immune checkpoint signaling in the TME is being explored, hinting towards a lead role for TAMs. While IFN- $\gamma$ is the main regulator of PD-L1 expression in tumor cells, PD-L1 expression in TAMs seems to be regulated via TNF $\alpha$ [119]. In 2017, Hartley et al. demonstrated that TNF $\alpha$ increases the expression of PD-L1 on bone marrow-derived monocytes and macrophages. They found that this was maintained through the secretion of versican by tumor cells, which stimulated the production of TNF $\alpha$ by monocytes themselves in a TLR2-dependent manner [120]. One year later, the same group provided more evidence on the interactions between the TNF $\alpha$ and PD-L1 pathways, as they demonstrated that PD-L1 blockade increased spontaneous macrophage proliferation, survival, and activation in vitro. Via RNAseq and IPA software analysis of these anti-PD-L1 treated macrophages, they further revealed an activated TNFR2 signaling profile [119]. Furthermore, it was recently shown in NSCLC patients that TNF $\alpha$-secreting TAMs can enhance hypoxia and aerobic glycolysis and that TAMs dampen PD-L1 expression on murine lung tumor cells specifically [121,122]. The latter does contradict the observation that TAM-secreted TNF $\alpha$ could stabilize PD-L1 expression on 4T1 mammary cancer cells, triggering immunosuppression in vivo [123].

As melanoma remains the textbook example for immunotherapy responsiveness, $\mathrm{TNF} \alpha$ targeting studies are most numerous for this cancer type. Overall, preclinical TNF $\alpha$ blockade has been shown to reduce the induction of irAEs upon ICI combinations and even improve therapeutic effectiveness of ICIs $[117,124]$. Upon adoptive CD8 ${ }^{+} \mathrm{T}$ cell transfer, $\mathrm{TNF} \alpha$ appeared to be a crucial factor in the incitement of melanoma dedifferentiation, which resulted in immune escape and melanoma relapse [125]. Bertrand et al. partly explained these effects by the observation that TNF $\alpha /$ TNFR1 signaling triggers AICD of tumor-infiltrating $\mathrm{CD}^{+} \mathrm{T}$ cells in melanoma, with subsequent lack of response to antiPD-1 therapy [126]. Hence, via systemic administration of etanercept, melanoma growth was inhibited in immunocompetent animals specifically. Notably, similar effects were seen in TNFR1-ko, but not TNFR2-ko, mice, suggestive for the decisive role of TNFR1 in 
this AICD of CD8 ${ }^{+} \mathrm{T}$ cells [127]. A few years later, Bertrand et al. further validated these findings by showing that anti-PD-1 therapy can stimulate T-cell expression of the alternative checkpoint T-cell immunoglobulin and mucin domain 3 (TIM-3) via TNF $\alpha$. Moreover, they could demonstrate that co-blockade of PD-1 and TNF $\alpha$ overcomes resistance to anti-PD-1 monotherapy [124]. Hence, we eagerly await the results from the first Phase $\mathrm{Ib}$, open-label trial [128] that is evaluating the administration of nivolumab (anti-PD-1) and ipilimumab (anti-CTLA-4) in combination with the anti-TNF $\alpha$ drug infliximab or certolizumab in patients with advanced melanoma.

In contrast to melanoma, only a handful of preclinical studies have explored the potential of TNF $\alpha$ pathway modulating strategies to treat lung cancer with rather contradictory findings. For example, anti-TNF $\alpha$ antibody treatment has been tested together with an intrapulmonary IFN-beta immuno-gene therapy (Ad.IFN $\beta$ ) in an orthotopic mouse model of lung cancer. The rationale for this was that blocking the pro-inflammatory actions of $\mathrm{TNF} \alpha$ could reduce the induction of dose-limiting pulmonary inflammation upon Ad.IFN $\beta$ delivery. However, upon administration, the anti-TNF $\alpha$ antibody not only significantly reduced the pulmonary inflammation but also the therapeutic effect of Ad.IFN $\beta$ delivery. Hence, TNF $\alpha$ proved to be both a dose-limiting factor as well as crucial for the anti-tumor immune stimulatory capacity of Ad.IFN $\beta$ [129]. More straightforward was the negative role described for TNF $\alpha$ secretion by TAMs, as this promoted cell glycolysis, tumor hypoxia, and decreased PD-L1 expression. Hence, when the TNF $\alpha$-secreting TAMs were depleted upon clodronate treatment of LLC-engrafted mice, PD-L1 expression significantly increased in the aerobic cancer cells. Moreover, this treatment increased tumor T cell infiltration and most importantly, its response to anti-PD-L1 therapy, which was otherwise completely ineffective [121]. While the above study suggests that TNF $\alpha$ blockade can increase effectivity of anti-PD-L1 therapy, this seems diametrically opposed to the observation that not reduced but increased serological levels of TNF $\alpha$ were found to be associated with improved anti-PD-1 treatment response and survival in NSCLC (along with IFN- $\gamma$, IL-1, IL-2, IL-4, IL-5, IL-6, IL-8, IL-10, and IL-12) [130]. Using an online available RNAseq dataset on $\mathrm{CD}^{+} \mathrm{T}$ cells sorted out of NSCLC patients' peripheral blood mononuclear cells before and during anti-PD-1 mAb therapy [131], we were able to support the notion that increased levels of sTNF $\alpha$ could be linked to improved anti-PD-1 treatment response, as we found a non-significant increase in TACE expression within the responder group specifically, linked to more release of sTNF $\alpha$ from its tmTNF $\alpha$ form (Figure 2E). While the TNFR1/TNFR2 ratio decreased upon anti-PD-1 treatment, this phenomenon was seen in both the responder and non-responder groups (Figure 2F). Finally, the levels of LTA were very similar between the responder and non-responder groups (data not shown), although we were unable to draw any conclusions for TNF due to the lack of representative data, underscoring the current lack of human data on gene expression profiles of the different $\mathrm{TNF} \alpha$ family members before, during, and after antitumor immunotherapy.

\section{Conclusions and Future Perspectives on TNF $\alpha$ Modulation for Lung Cancer Treatment}

The multitude of contradictory findings currently poses a stalemate for TNF $\alpha$ pathwayaffecting strategies in combination with immunotherapy to treat lung cancer and suggests the need for additional research into biomarkers to guide rationalized therapy combinations. This conundrum is reflected by the range of preclinical studies that report on the therapeutic efficacy of TNF $\alpha$ upon its administration as well as its inhibition [132]. To illustrate, when a TNF-based Activity-on-Target cytokine (AcTakine) was specifically targeted to the $\mathrm{CD} 13^{+}$ neovasculature in vivo, the rapid destruction of the tumor neovasculature and complete regression of large, established tumors was demonstrated. In contrast, selective blockage of STNF $\alpha$ via INB03 led to a reduced carcinogen-induced tumor incidence and growth rate [133]. Moreover, a detrimental role has been attributed to sTNF $\alpha$ and TNFR1 for melanoma-infiltrated functional $\mathrm{CD} 8^{+} \mathrm{T}$ cells as well as the onset of irAEs, rationalizing combined $\mathrm{TNF} \alpha$-blockade with immunotherapy to treat melanoma. 
By mining existing next-generation sequencing data from LUAD patients, the latter were shown to contain less TNF, and because of the significant reduction in TACE, sTNF $\alpha$ protein is likely to be most decreased. Together with the notion that $\operatorname{tmTNF} \alpha$, and not $\operatorname{sTNF} \alpha$, has been shown to play a key role in Th1-polarized antitumor immunity and improved lung cancer patient survival $[18,134]$, this argues against a tumor promoting role for TNF $\alpha$ in lung cancer, discouraging TNF $\alpha$-blockage for lung cancer treatment today. Additionally, the role of TNFR2 in lung cancer progression remains undetermined and requires more research. High amounts of TNFR2 $2^{+}$Tregs have been found in the TME of human advanced lung cancers, and TNFR2 has recently been identified as a tumor-promoting oncogene with new biomarker potential for cancer $[135,136]$. However, upon mining the currently available transcriptomic dataset from a TCGA LUAD patient cohort, we demonstrated that the expression of TNFR2 is markedly decreased in the lung TME. Moreover, pre-clinically, TNFR2 agonists as well as antagonists have been linked to antitumoral effects, arguing against the effectiveness of TNFR2 modulation for lung cancer therapy [137-140].

To conclude, numerous studies point out that TNF $\alpha$ signaling is extensively involved in lung tumor progression and response to (immuno-)therapy. However, the underlying mechanisms of the different TNF $\alpha$ family members that modulate tumor prognosis and response to treatment remain to be revealed. We summarized our main findings in Figure 3 to highlight that TNF $\alpha$ signaling involves different ligands and receptors in LUAD, which have been linked to prognosis response to PD-(L)1 treatment. To make matters more complicated, all of these components can be expressed, secreted, and sensed by a broad range of malignant, immune, and non-immune cells within the respiratory tract, whereas most (pre-)clinical data have been based on serological values of sTNF $\alpha$ and RNA sequencing data. Therefore, we believe that larger genomic, transcriptomic, and proteomic dataset analysis studies are needed for various disease stages and treatment options on the single cell lung TME level to advance our current understanding of the biomarker and modulatory potential of the TNF $\alpha$ pathway for lung cancer prognosis and therapy.

Funding: K.D.R. and C. Goyvaerts were supported by Kom op tegen Kanker, Fonds Wetenschappelijk Onderzoek (FWO) Vlaanderen, Wetenschappelijk Fonds Willy Gepts, and the BCLAS Fund in honor of Jean René Maisin.

Conflicts of Interest: The authors declare no conflict of interest.

\section{References}

1. Carswell, E.A.; Old, L.J.; Kassel, R.L.; Green, S.; Fiore, N.; Williamson, B. An endotoxin-induced serum factor that causes necrosis of tumors. Proc. Natl. Acad. Sci. USA 1975, 72, 3666. [CrossRef]

2. Aggarwal, B.B.; Gupta, S.C.; Kim, J.H. Historical perspectives on tumor necrosis factor and its superfamily: 25 years later, a golden journey. Blood 2012, 119, 651. [CrossRef]

3. Baeyens, K.J.; de Bondt, H.L.; Raeymaekers, A.; Fiers, W.; de Ranter, C.J. IUCr the structure of mouse tumour-necrosis factor at 1.4 å resolution: Towards modulation of its -selectivity and trimerization. Acta Crystallogr. 1999, 55, 772-778. [CrossRef]

4. Schall, T.J.; Lewis, M.; Koller, K.J.; Lee, A.; Rice, G.C.; Wong, G.H.W.; Gatanaga, T.; Granger, G.A.; Lentz, R.; Raab, H.; et al. Molecular cloning and expression of a receptor for human tumor necrosis factor. Cell 1990, 61, 361-370. [CrossRef]

5. Loetscher, H.; Pan, Y.-C.E.; Lahm, H.-W.; Gentz, R.; Brockhaus, M.; Tabuchi, H.; Lesslauer, W. Molecular cloning and expression of the human $55 \mathrm{kd}$ tumor necrosis factor receptor. Cell 1990, 61, 351-359. [CrossRef]

6. Parameswaran, N.; Patial, S. Tumor necrosis factor-alpha signaling in macrophages. Crit. Rev. Eukaryot. Gene Expr. 2010, 20, 87-103. [CrossRef]

7. Bradley, J. TNF-mediated inflammatory disease. J. Pathol. 2008, 214, 149-160. [CrossRef]

8. Mehta, A.K.; Gracias, D.T.; Croft, M. TNF activity and t cells. Cytokine 2018, 101, 14. [CrossRef]

9. Armstrong, L.; Thickett, D.R.; Christie, S.J.; Kendall, H.; Millar, A.B. Increased expression of functionally active membraneassociated tumor necrosis factor in acute respiratory distress syndrome. Am. J. Respir. Cell Mol. Biol. 2012, 22, 68-74. [CrossRef]

10. Williams, M.A.; Newland, A.C.; Kelsey, S.M. Cytokine modulated cell-membrane bound tumour necrosis factor expression is associated with enhanced monocyte-mediated killing of human leukaemic targets. Leuk. Res. 2000, 24, 317-330. [CrossRef]

11. Horiuchi, T.; Morita, C.; Tsukamoto, H.; Mitoma, H.; Sawabe, T.; Harashima, S.-I.; Kashiwagi, Y.; Okamura, S. Increased expression of membrane tnf- $\alpha$ on activated peripheral cd8+t cells in systemic lupus erythematosus. Int. J. Mol. Med. 2006, 17, 875-879. [CrossRef] 
12. Caron, G.; Delneste, Y.; Aubry, J.-P.; Magistrelli, G.; Herbault, N.; Blaecke, A.; Meager, A.; Bonnefoy, J.-Y.; Jeannin, P. Human NK cells constitutively express membrane tnf- $\alpha(\mathrm{mtnf} \alpha)$ and present $\mathrm{mtnf} \alpha$-dependent cytotoxic activity. Eur. J. Immunol. 1999, 29, 3588-3595. [CrossRef]

13. Xu, H.; Sethi, J.K.; Hotamisligil, G.S. Transmembrane tumor necrosis factor (TNF)- $\alpha$ inhibits adipocyte differentiation by selectively activating tnf receptor 1. J. Biol. Chem. 1999, 274, 26287-26295. [CrossRef]

14. Qu, Y.; Zhao, G.; Li, H. Forward and reverse signaling mediated by transmembrane tumor necrosis factor-alpha and tnf receptor 2: Potential roles in an immunosuppressive tumor microenvironment. Front. Immunol. 2017, 8, 1675. [CrossRef] [PubMed]

15. Caldwell, A.B.; Cheng, Z.; Vargas, J.D.; Birnbaum, H.A.; Hoffmann, A. Network Dynamics determine the autocrine and paracrine signaling functions of TNF. Genes Dev. 2014, 28, 2120-2133. [CrossRef] [PubMed]

16. FionulaM, B.; Jackson, A.; Chantry, D.; Maini, R.; Feldmann, M. Inhibitory effect of tnf alpha antibodies on synovial cell interleukin-1 production in rheumatoid arthritis. Lancet 1989, 334, 244-247. [CrossRef]

17. Marino, M.W.; Dunn, A.; Grail, D.; Inglese, M.; Noguchi, Y.; Richards, E.; Jungbluth, A.; Wada, H.; Moore, M.; Williamson, B.; et al. Characterization of tumor necrosis factor-deficient mice. Proc. Natl. Acad. Sci. USA 1997, 94, 8093-8098. [CrossRef] [PubMed]

18. Xu, J.; Chakrabarti, A.K.; Tan, J.L.; Ge, L.; Gambotto, A.; Vujanovic, N.L. Essential role of the TNF-TNFR2 cognate interaction in mouse dendritic cell-natural killer cell crosstalk. Blood 2007, 109, 3333-3341. [CrossRef]

19. Horiuchi, T.; Mitoma, H.; Harashima, S.; Tsukamoto, H.; Shimoda, T. Transmembrane TNF- $\alpha$ : Structure, function and interaction with anti-tnf agents. Rheumatology 2010, 49, 1215-1228. [CrossRef]

20. Parry, S.L.; Sebbag, M.; Feldmann, M.; Brennan, F.M. Contact with T cells modulates monocyte il-10 production: Role of T cell membrane TNF-Alpha. J. Immunol. 1997, 158, 3673-3681.

21. Rossol, M.; Meusch, U.; Pierer, M.; Kaltenhäuser, S.; Häntzschel, H.; Hauschildt, S.; Wagner, U. Interaction between transmembrane tnf and tnfr1/2 mediates the activation of monocytes by contact with T cells. J. Immunol. 2007, 179, 4239-4248. [CrossRef]

22. Eissner, G.; Kolch, W.; Scheurich, P. Ligands working as receptors: Reverse signaling by members of the TNF superfamily enhance the plasticity of the immune system. Cytokine Growth Factor Rev. 2004, 15, 353-366. [CrossRef]

23. Deng, J.; Zhao, X.; Rong, L.; Li, X.; Liu, X.; Qin, Z. TNFR-1 on tumor cells contributes to the sensitivity of fibrosarcoma to chemotherapy. Protein Cell 2013, 4, 393. [CrossRef]

24. Zhao, Y.; Yang, F.; Li, W.; Xu, C.; Li, L.; Chen, L.; Liu, Y.; Sun, P. MiR-29a suppresses MCF-7 cell growth by downregulating tumor necrosis factor receptor 1. Tumor Biol. 2017, 39, 1010428317692264. [CrossRef]

25. Yang, Z.; Wang, Y.; Zhang, L.; Zhao, C.; Wang, D. Phosphorylated form of pyruvate dehydrogenase $\alpha 1$ mediates tumor necrosis factor $\alpha$ induced glioma cell migration. Oncol. Lett. 2021, 21, 176. [CrossRef]

26. Hwang, H.S.; Park, Y.-Y.; Shin, S.-J.; Go, H.; Park, J.-M.; Yoon, S.Y.; Lee, J.-L.; Cho, Y.M. Involvement of the TNF- $\alpha$ pathway in TKI resistance and suggestion of TNFR1 as a predictive biomarker for TKI responsiveness in clear cell renal cell carcinoma. J. Korean Med. Sci. 2020, 35, e31. [CrossRef] [PubMed]

27. Huang, P.; Rani, M.R.S.; Ahluwalia, M.S.; Bae, E.; Prayson, R.A.; Weil, R.J.; Nowacki, A.S.; Hedayat, H.; Sloan, A.E.; Lathia, J.D.; et al. Endothelial expression of TNF receptor-1 generates a proapoptotic signal inhibited by integrin A6 31 in glioblastoma. Cancer Res. 2012, 72, 1428-1437. [CrossRef] [PubMed]

28. Wajant, H.; Siegmund, D. TNFR1 and TNFR2 in the control of the life and death balance of macrophages. Front. Cell Dev. Biol. 2019, 91. [CrossRef] [PubMed]

29. Polz, J.; Remke, A.; Weber, S.; Schmidt, D.; Weber-Steffens, D.; Pietryga-Krieger, A.; Müller, N.; Ritter, U.; Mostböck, S.; Männel, D.N. Myeloid suppressor cells require membrane TNFR2 expression for suppressive activity. Immun. Inflamm. Dis. 2014, 2, 121-130. [CrossRef] [PubMed]

30. Faustman, D.; Davis, M. TNF receptor 2 pathway: Drug target for autoimmune diseases. Nat. Rev. Drug Discov. 2010, 9, 482-493. [CrossRef] [PubMed]

31. Grell, M.; Wajant, H.; Zimmermann, G.; Scheurich, P. The type 1 receptor (CD120a) is the high-affinity receptor for soluble tumor necrosis factor. Proc. Natl. Acad. Sci. USA 1998, 95, 570-575. [CrossRef]

32. Grell, M.; Douni, E.; Wajant, H.; Löhden, M.; Clauss, M.; Maxeiner, B.; Scheurich, P. The transmembrane form of tumor necrosis factor is the prime activating ligand of the $80 \mathrm{KDa}$ tumor necrosis factor receptor. Cell 1995, 83, 793-802. [CrossRef]

33. Ding, X.; Yang, W.; Shi, X.; Du, P.; Su, L.; Qin, Z.; Chen, J.; Deng, H. TNF receptor 1 mediates dendritic cell maturation and CD8 T cell response through two distinct mechanisms. J. Immunol. 2011, 187, 1184-1191. [CrossRef]

34. Yang, S.; Xie, C.; Chen, Y.; Wang, J.; Chen, X.; Lu, Z.; June, R.R.; Zheng, S.G. Differential roles of TNF $\alpha$-TNFR1 and TNF $\alpha$-TNFR2 in the differentiation and function of CD4 + Foxp3 + induced treg cells in vitro and in vivo periphery in auto. Cell Death Dis. 2019, 10, 27. [CrossRef] [PubMed]

35. Almishri, W.; Santodomingo-Garzon, T.; Le, T.; Stack, D.; Mody, C.H.; Swain, M.G. TNF $\alpha$ Augments cytokine-induced NK cell IFN $\gamma$ production through TNFR2. J. Innate Immun. 2016, 8, 617-629. [CrossRef]

36. Zheng, L.; Fisher, G.; Miller, R.E.; Peschon, J.; Lynch, D.H.; Lenardo, M.J. Induction of apoptosis in mature T cells by tumour necrosis factor. Nature 1995, 377, 348-351. [CrossRef]

37. Chen, X.; Bäumel, M.; Männel, D.N.; Howard, O.M.Z.; Oppenheim, J.J. Interaction of TNF with TNF receptor type 2 promotes expansion and function of mouse CD4+CD25+ T regulatory cells. J. Immunol. 2007, 179, 154-161. [CrossRef] [PubMed] 
38. Zhong, H.; Bussel, J.; Yazdanbakhsh, K. In Vitro TNF blockade enhances Ex vivo expansion of regulatory T cells in patients with immune thrombocytopenia. Br. J. Haematol. 2015, 168, 274-283. [CrossRef]

39. Chopra, M.; Lang, I.; Salzmann, S.; Pachel, C.; Kraus, S.; Bäuerlein, C.A.; Brede, C.; Garrote, A.-L.J.; Mattenheimer, K.; Ritz, M.; et al. Tumor necrosis factor induces tumor promoting and anti-tumoral effects on pancreatic cancer via TNFR1. PLoS ONE 2013, 8, 75737. [CrossRef] [PubMed]

40. Philippe, C.; Roux-Lombard, P.; Fouqueray, B.; Perez, J.; Dayer, J.M.; Baud, L. Membrane expression and shedding of tumour necrosis factor receptors during activation of human blood monocytes: Regulation by desferrioxamine. Immunology 1993, 80, 300. [PubMed]

41. Rochemonteix, B.G.; Nicod, L.P.; Dayer, J.M. Tumor necrosis factor soluble receptor 75: The Principal receptor form released by human alveolar macrophages and monocytes in the presence of interferon gamma. Am. J. Respir. Cell Mol. Biol. 2012, 14, 279-287. [CrossRef]

42. Lainez, B.; Fernandez-Real, J.M.; Romero, X.; Esplugues, E.; Cañete, J.D.; Ricart, W.; Engel, P. Identification and characterization of a novel spliced variant that encodes human soluble tumor necrosis factor receptor 2. Int. Immunol. 2004, 16, 169-177. [CrossRef]

43. Mierlo, G.J.D.v.; Scherer, H.U.; Hameetman, M.; Morgan, M.E.; Flierman, R.; Huizinga, T.W.J.; Toes, R.E.M. Cutting edge: TNFR-shedding by CD4+CD25+ regulatory T cells inhibits the induction of inflammatory mediators. J. Immunol. 2008, 180, 2747-2751. [CrossRef] [PubMed]

44. Xanthoulea, S.; Pasparakis, M.; Kousteni, S.; Brakebusch, C.; Wallach, D.; Bauer, J.; Lassmann, H.; Kollias, G. Tumor necrosis factor (TNF) receptor shedding controls thresholds of innate immune activation that balance opposing TNF functions in infectious and inflammatory diseases. J. Exp. Med. 2004, 200, 367-376. [CrossRef] [PubMed]

45. Naudé, P.J.W.; Boer, J.A.d.; Luiten, P.G.M.; Eisel, U.L.M. Tumor necrosis factor receptor cross-talk. FEBS J. 2011, $278,888-898$. [CrossRef] [PubMed]

46. Varfolomeev, E.; Vucic, D. Intracellular regulation of TNF activity in health and disease. Cytokine 2018, 101, 26-32. [CrossRef]

47. Vandenabeele, P.; Declercq, W.; Beyaert, R.; Fiers, W. Two tumour necrosis factor receptors: Structure and function. Trends Cell Biol. 1995, 5, 392-399. [CrossRef]

48. Hayden, M.S.; Ghosh, S. Regulation of NF-KB by TNF family cytokines. Semin. Immunol. 2014, 26, 253. [CrossRef]

49. Yang, S.; Wang, J.; Brand, D.D.; Zheng, S.G. Role of TNF-TNF receptor 2 signal in regulatory T cells and its therapeutic implications. Front. Immunol. 2018, 9, 784. [CrossRef]

50. Rauert, H.; Wicovsky, A.; Müller, N.; Siegmund, D.; Spindler, V.; Waschke, J.; Kneitz, C.; Wajant, H. membrane tumor necrosis factor (TNF) induces P100 processing via TNF receptor-2 (TNFR2). J. Biol. Chem. 2010, 285, 7394-7404. [CrossRef]

51. Zhang, W.; Liu, H.T. MAPK Signal pathways in the regulation of cell proliferation in mammalian cells. Cell Res. 2002, 12, 9-18. [CrossRef]

52. Ichijo, H. From receptors to stress-activated MAP kinases. Oncogene 1999, 18, 6087-6093. [CrossRef] [PubMed]

53. Natoli, G.; Costanzo, A.; Ianni, A.; Templeton, D.J.; Woodgett, J.R.; Balsano, C.; Levrero, M. Activation of SAPK/JNK by TNF receptor 1 through a noncytotoxic TRAF2-dependent pathway. Science 1997, 275, 200-203. [CrossRef] [PubMed]

54. Medvedev, A.E.; Espevik, T.; Ranges, G.; Sundan, A. Distinct roles of the two tumor necrosis factor (TNF) receptors in modulating TNF and lymphotoxin $\alpha$ effects. J. Biol. Chem. 1996, 271, 9778-9784. [CrossRef]

55. Gubernatorova, E.O.; Polinova, A.I.; Petropavlovskiy, M.M.; Namakanova, O.A.; Medvedovskaya, A.D.; Zvartsev, R.V.; Telegin, G.B.; Drutskaya, M.S.; Nedospasov, S.A. Dual role of TNF and LT $\alpha$ in carcinogenesis as implicated by studies in mice. Cancers 2021, 13, 1775. [CrossRef] [PubMed]

56. Jiang, H.; Hampel, H.; Prvulovic, D.; Wallin, A.; Blennow, K.; Li, R.; Shen, Y. Elevated CSF levels of TACE activity and soluble TNF receptors in subjects with mild cognitive impairment and patients with Alzheimer's disease. Mol. Neurodegener. $2011,6,69$. [CrossRef]

57. Waters, J.P.; Pober, J.S.; Bradley, J.R. Tumour necrosis factor and cancer. J. Pathol. 2013, 230, 241-248. [CrossRef] [PubMed]

58. Nooijen, P.T.; Manusama, E.R.; Eggermont, A.M.; Schalkwijk, L.; Stavast, J.; Marquet, R.L.; de Waal, R.M.; Ruiter, D.J. Synergistic effects of TNF-Alpha and melphalan in an isolated limb perfusion model of rat sarcoma: A histopathological, immunohistochemical and electron microscopical study. Br. J. Cancer 1996, 74, 1908. [CrossRef]

59. Van Horssen, R.; ten Hagen, T.L.M.; Eggermont, A.M.M. TNF- $\alpha$ in Cancer treatment: Molecular insights, antitumor effects, and clinical utility. Oncologist 2006, 11, 397-408. [CrossRef]

60. Bradley, J.R.; Thiru, S.; Pober, J.S. Disparate localization of 55-Kd and 75-Kd tumor necrosis factor receptors in human endothelial cells. Am. J. Pathol. 1995, 146, 27.

61. Brouckaert, P.; Takahashi, N.; van Tiel, S.T.; Hostens, J.; Eggermont, A.M.M.; Seynhaeve, A.L.B.; Fiers, W.; Hagen, T.L.M. Ten tumor necrosis factor- $\alpha$ augmented tumor response in B16BL6 melanoma-bearing mice treated with stealth liposomal doxorubicin $\left(\right.$ Doxil $\left.^{\circledR}\right)$ correlates with altered Doxil ${ }^{\circledR}$ pharmacokinetics. Int. J. Cancer 2004, 109, 442-448. [CrossRef] [PubMed]

62. Ten Hagen, T.L.M.; van der Veen, A.H.; Nooijen, P.T.G.A.; van Tiel, S.T.; Seynhaeve, A.L.B.; Eggermont, A.M.M. Low-dose tumor necrosis factor- $\alpha$ augments antitumor activity of stealth liposomal doxorubicin (DOXIL ${ }^{\circledR}$ ) in soft tissue sarcoma-bearing rats. J. Cancer 2000, 87, 829-837. [CrossRef]

63. Veen, A.H.v.d.; Wilt, J.H.W.d.; Eggermont, A.M.M.; Tiel, S.T.v.; Seynhaeve, A.L.B.; Hagen, T.L.M. Ten TNF- $\alpha$ augments intratumoural concentrations of doxorubicin in TNF- $\alpha$-based isolated limb perfusion in rat sarcoma models and enhances anti-tumour effects. Br. J. Cancer 2000, 82, 973. [CrossRef] 
64. Fràter-Schröder, M.; Risau, W.; Hallmann, R.; Gautschi, P.; Böhlen, P. Tumor necrosis factor type alpha, a potent inhibitor of endothelial cell growth in vitro, is angiogenic in vivo. Proc. Natl. Acad. Sci. USA 1987, 84, 5277. [CrossRef]

65. Sainson, R.C.A.; Johnston, D.A.; Chu, H.C.; Holderfield, M.T.; Nakatsu, M.N.; Crampton, S.P.; Davis, J.; Conn, E.; Hughes, C.C.W. TNF primes endothelial cells for angiogenic sprouting by inducing a tip cell phenotype. Blood 2008, 111, 4997-5007. [CrossRef]

66. Giraudo, E.; Primo, L.; Audero, E.; Gerber, H.-P.; Koolwijk, P.; Soker, S.; Klagsbrun, M.; Ferrara, N.; Bussolino, F. Tumor necrosis factor- $\alpha$ regulates expression of vascular endothelial growth factor receptor-2 and of its co-receptor neuropilin-1 in human vascular endothelial cells. J. Biol. Chem. 1998, 273, 22128-22135. [CrossRef]

67. Patterson, C.; Perrella, M.A.; Endege, W.O.; Yoshizumi, M.; Lee, M.E.; Haber, E. Downregulation of vascular endothelial growth factor receptors by tumor necrosis factor-alpha in cultured human vascular endothelial cells. J. Clin. Investig. 1996, 98, 490. [CrossRef]

68. Fajardo, L.; Kwan, H.; Kowalski, J.; Prionas, D.; Allison, A. Dual role of tumor necrosis factor-alpha in angiogenesis. Am. J. Pathol. 1992, 140, 539-544.

69. Gina, L.; Tonya, C.W.; Steven, M.D. Chronic inflammation, chronic obstructive pulmonary disease, and lung cancer. Curr. Opin. Pulm. Med. 2009, 15, 303-307. [CrossRef]

70. Greten, F.R.; Grivennikov, S.I. Inflammation and cancer: Triggers, mechanisms, and consequences. Immunity 2019, 51, 27-41. [CrossRef]

71. Yan, B.; Wang, H.; Rabbani, Z.N.; Zhao, Y.; Li, W.; Yuan, Y.; Li, F.; Dewhirst, M.W.; Li, C.-Y. Tumor necrosis factor- $\alpha$ is a potent endogenous mutagen that promotes cellular transformation. Cancer Res. 2006, 66, 11565-11570. [CrossRef]

72. Grivennikov, S.I. Inflammation and colorectal cancer: Colitis-associated neoplasia. Semin. Immunopathol. 2012, 35, 229-244. [CrossRef]

73. Suarez-Carmona, M.; Lesage, J.; Cataldo, D.; Gilles, C. EMT and inflammation: Inseparable actors of cancer progression. Mol. Oncol. 2017, 11, 805-823. [CrossRef] [PubMed]

74. Balkwill, F. TNF- $\alpha$ in promotion and progression of cancer. Cancer Metastasis Rev. 2006, 25, 409-416. [CrossRef] [PubMed]

75. Gaur, U.; Aggarwal, B.B. Regulation of proliferation, survival and apoptosis by members of the TNF superfamily. Biochem. Pharmacol. 2003, 66, 1403-1408. [CrossRef]

76. Idriss, T.H.; Naismith, H. James TNF $\alpha$ and the TNF receptor superfamily: Structure-function relationship(s). Microsc. Res. Tech. 2000, 50, 184-195. [CrossRef]

77. Huang, Y.; Yu, X.; Wang, L.; Zhou, S.; Sun, J.; Feng, N.; Nie, S.; Wu, J.; Gao, F.; Fei, B.; et al. Four genetic polymorphisms of lymphotoxin-alpha gene and cancer risk: A systematic review and meta-analysis. PLoS ONE 2013, 8, e82519. [CrossRef]

78. Vesely, M.D.; Schreiber, R.D. Cancer immunoediting: Antigens, mechanisms, and implications to cancer immunotherapy. Ann. N. Y. Acad. Sci. 2013, 1284, 1-5. [CrossRef] [PubMed]

79. McCoach, C.E.; Bivona, T.G. The evolving understanding of immunoediting and the clinical impact of immune escape. J. Thorac. Dis. 2018, 10, 1248-1252. [CrossRef] [PubMed]

80. Mittal, D.; Gubin, M.M.; Schreiber, R.D.; Smyth, M.J. New insights into cancer immunoediting and its three component phases —elimination, equilibrium and escape. Curr. Opin. Immunol. 2014, 27, 16-25. [CrossRef] [PubMed]

81. Kratochvill, F.; Neale, G.; Haverkamp, J.M.; Van de Velde, L.-A.; Smith, A.M.; Kawauchi, D.; McEvoy, J.; Roussel, M.F.; Dyer, M.A.; Qualls, J.E.; et al. TNF counterbalances the emergence of M2 tumor macrophages. Cell Rep. 2015, 12, 1902-1914. [CrossRef]

82. Braumüller, H.; Wieder, T.; Brenner, E.; Aßmann, S.; Hahn, M.; Alkhaled, M.; Schilbach, K.; Essmann, F.; Kneilling, M.; Griessinger, C.; et al. T-helper-1-cell cytokines drive cancer into senescence. Nature 2013, 494, 361-365. [CrossRef]

83. Müller-Hermelink, N.; Braumüller, H.; Pichler, B.; Wieder, T.; Mailhammer, R.; Schaak, K.; Ghoreschi, K.; Yazdi, A.; Haubner, R.; Sander, C.A.; et al. TNFR1 signaling and IFN- $\gamma$ signaling determine whether T cells induce tumor dormancy or promote multistage carcinogenesis. Cancer Cell 2008, 13, 507-518. [CrossRef] [PubMed]

84. Schioppa, T.; Moore, R.; Thompson, R.G.; Rosser, E.C.; Kulbe, H.; Nedospasov, S.; Mauri, C.; Coussens, L.M.; Balkwill, F.R. B regulatory cells and the tumor-promoting actions of TNF- $\alpha$ during squamous carcinogenesis. Proc. Natl. Acad. Sci. USA 2011, 108, 10662-10667. [CrossRef]

85. Zhao, X.; Rong, L.; Zhao, X.; Li, X.; Liu, X.; Deng, J.; Wu, H.; Xu, X.; Erben, U.; Wu, P.; et al. TNF Signaling drives myeloid-derived suppressor cell accumulation. J. Clin. Investig. 2012, 122, 4094-4104. [CrossRef]

86. Sayed, M.F.a.; Amrein, M.A.; Bührer, E.D.; Huguenin, A.-L.; Radpour, R.; Riether, C.; Ochsenbein, A.F. T-cell-secreted TNF $\alpha$ induces emergency myelopoiesis and myeloid-derived suppressor cell differentiation in cancer. Cancer Res. 2019, 79, 346-359. [CrossRef]

87. Hu, X.; Li, B.; Li, X.; Zhao, X.; Wan, L.; Lin, G.; Yu, M.; Wang, J.; Jiang, X.; Feng, W.; et al. Transmembrane TNF- $\alpha$ promotes suppressive activities of myeloid-derived suppressor cells via TNFR2. J. Immunol. 2014, 192, 1320-1331. [CrossRef]

88. Liu, Y.; Ji, X.; Kang, N.; Zhou, J.; Liang, X.; Li, J.; Han, T.; Zhao, C.; Yang, T. Tumor necrosis factor $\alpha$ inhibition overcomes immunosuppressive M2b macrophage-induced bevacizumab resistance in triple-negative breast cancer. Cell Death Dis. 2020, 11, 1-13. [CrossRef]

89. Lung Statistics, Globocan, Number of New Cases. 2020. Available online: https://Gco.Iarc.Fr/Today/Data/Factsheets/Cancers/ 15-Lung-Fact-Sheet.Pdf (accessed on 1 July 2021). 
90. Travis, W.D.; Brambilla, E.; Nicholson, A.G.; Yatabe, Y.; Austin, J.H.M.; Beasley, M.B.; Chirieac, L.R.; Dacic, S.; Duhig, E.; Flieder, D.B.; et al. The 2015 world health organization classification of lung tumors: Impact of genetic, clinical and radiologic advances since the 2004 classification. J. Thorac. Oncol. 2015, 10, 1243-1260. [CrossRef] [PubMed]

91. Hartl, D.; Tirouvanziam, R.; Laval, J.; Greene, C.M.; Habiel, D.; Sharma, L.; Yildirim, A.Ö.; Dela Cruz, C.S.; Hogaboam, C.M. Innate immunity of the lung: From basic mechanisms to translational medicine. J. Innate Immun. 2018, 10, 487-501. [CrossRef] [PubMed]

92. Ermert, M.; Pantazis, C.; Duncker, H.R.; Grimminger, F.; Seeger, W.; Ermert, L. In situ localization of TNF $\alpha / \beta$, tace and TNF Receptors TNF-R1 and TNF-R2 in control and LPS-treated lung tissue. Cytokine 2003, 22, 89-100. [CrossRef]

93. Spella, M.; Stathopoulos, G.T. Immune resistance in lung adenocarcinoma. Cancers 2021, 13, 384. [CrossRef]

94. Shih, C.-M.; Lee, Y.-L.; Chiou, H.-L.; Chen, W.; Chang, G.-C.; Chou, M.-C.; Lin, L.-Y. Association of TNF- $\alpha$ polymorphism with susceptibility to and severity of non-small cell lung cancer. Lung Cancer 2006, 52, 15-20. [CrossRef] [PubMed]

95. Xie, H.; Yao, H.; Huo, Y.; Li, N.; Cheng, Y. Association between TNF- $\alpha$ gene 308G >A polymorphism and lung cancer risk: A meta-analysis. Tumor Biol. 2014, 35, 9693-9699. [CrossRef]

96. Ardestani, S.; Li, B.; Deskins, D.L.; Wu, H.; Massion, P.P.; Young, P.P. Membrane versus soluble isoforms of TNF- $\alpha$ exert opposing effects on tumor growth and survival of tumor-associated myeloid cells. Cancer Res. 2013, 73, 3938-3950. [CrossRef]

97. Yu, W.-N.; Lai, Y.-J.; Ma, J.-W.; Ho, C.-T.; Hung, S.-W.; Chen, Y.-H.; Chen, C.-T.; Kao, J.-Y.; Way, T.-D. Citronellol induces necroptosis of human lung cancer cells via TNF- $\alpha$ pathway and reactive oxygen species accumulation. In Vivo 2019, 33, 1193-1201. [CrossRef] [PubMed]

98. Dimitrakopoulos, F.-I.D.; Kottorou, A.E.; Antonacopoulou, A.G.; Panagopoulos, N.; Scopa, C.; Kalofonou, M.; Dougenis, D.; Koutras, A.; Makatsoris, T.; Tzelepi, V.; et al. Expression of immune system-related membrane receptors CD40, RANK, BAFFR and LT $\beta R$ Is associated with clinical outcome of operated non-small-cell lung cancer patients. J. Clin. Med. 2019, 8, 741. [CrossRef]

99. Ren, S.; Tian, Q.; Amar, N.; Yu, H.; Rivard, C.J.; Caldwell, C.; Ng, T.L.; Tu, M.; Liu, Y.; Gao, D.; et al. The immune checkpoint, HVEM may contribute to immune escape in non-small cell lung cancer lacking PD-L1 expression. Lung Cancer 2018, 125, 115-120. [CrossRef] [PubMed]

100. Díez-Villanueva, A.; Mallona, I.; Peinado, M.A. Wanderer, an interactive viewer to explore DNA methylation and gene expression data in human cancer. Epigenetics Chromatin 2015, 8, 1-8. [CrossRef]

101. Shang, G.-S.; Liu, L.; Qin, Y.-W. IL-6 and TNF- $\alpha$ promote metastasis of lung cancer by inducing epithelial-mesenchymal transition. Oncol. Lett. 2017, 13, 4657. [CrossRef] [PubMed]

102. Chae, Y.; Chang, S.; Ko, T.; Anker, J.; Agte, S.; Iams, W.; Choi, W.; Lee, K.; Cruz, M. Epithelial-mesenchymal transition (EMT) signature is inversely associated with T-cell infiltration in non-small cell lung cancer (NSCLC). Sci. Rep. 2018, 8. [CrossRef]

103. Gong, L.; Caetano, M.d.S.; Cumpian, A.M.; Daliri, S.; Flores, A.G.; Chang, S.H.; Ochoa, C.E.; Evans, C.M.; Yu, Z.; Moghaddam, S.J. Tumor necrosis factor links chronic obstructive pulmonary disease and K-ras mutant lung cancer through induction of an immunosuppressive pro-tumor microenvironment. Oncoimmunology 2016, 5, e1229724. [CrossRef]

104. Guo, N.; Wen, Y.; Wang, C.; Kang, L.; Wang, X.; Liu, X.; Soulika, A.M.; Liu, B.; Zhao, M.; Han, X.; et al. Lung adenocarcinomarelated TNF- $\alpha$-dependent inflammation upregulates MHC-II on alveolar type II cells through CXCR-2 to contribute to treg expansion. FASEB J. 2020, 34, 12197-12213. [CrossRef]

105. Yang, Y.; Islam, M.S.; Hu, Y.; Chen, X. TNFR2: Role in cancer immunology and immunotherapy. ImmunoTargets Ther. 2021, 10, 103-122. [CrossRef]

106. Zhang, Y.W.; Chen, Q.Q.; Cao, J.; Xu, L.Q.; Tang, X.; Wang, J.; Zhang, J.; Dong, L.X. Expression of tumor necrosis factor receptor 2 in human non-small cell lung cancer and its role as a potential prognostic biomarker. Thorac. Cancer 2019, 10, 437. [CrossRef]

107. Chen, X.; Subleski, J.J.; Kopf, H.; Howard, O.M.Z.; Männel, D.N.; Oppenheim, J.J. Cutting edge: Expression of TNFR2 defines a maximally suppressive subset of mouse CD4+ CD25+ FoxP3+ T regulatory cells: Applicability to tumor-infiltrating t regulatory Cells. J. Immunol. 2008, 180, 6467-6471. [CrossRef]

108. Yan, F.; Du, R.; Wei, F.; Zhao, H.; Yu, J.; Wang, C.; Zhan, Z.; Ding, T.; Ren, X.; Chen, X.; et al. Expression of TNFR2 by regulatory $\mathrm{T}$ cells in peripheral blood is correlated with clinical pathology of lung cancer patients. Cancer Immunol. Immunother. 2015, 64, 1475-1485. [CrossRef]

109. Williams, G.S.; Mistry, B.; Guillard, S.; Ulrichsen, J.C.; Sandercock, A.M.; Wang, J.; González-Muñoz, A.; Parmentier, J.; Black, C.; Soden, J.; et al. Phenotypic screening reveals TNFR2 as a promising target for cancer immunotherapy. Oncotarget 2016, 7, 68278-68291. [CrossRef]

110. Sasi, S.P.; Bae, S.; Song, J.; Perepletchikov, A.; Schneider, D.; Carrozza, J.; Yan, X.; Kishore, R.; Enderling, H.; Goukassian, D.A. Therapeutic non-toxic doses of TNF induce significant regression in TNFR2-P75 knockdown lewis lung carcinoma tumor Implants. PLoS ONE 2014, 9, 92373. [CrossRef]

111. Ham, B.; Wang, N.; D’Costa, Z.; Fernandez, M.C.; Bourdeau, F.; Auguste, P.; Illemann, M.; Eefsen, R.L.; Høyer-Hansen, G.; Vainer, B.; et al. TNF receptor-2 facilitates an immunosuppressive microenvironment in the liver to promote the colonization and growth of hepatic metastases. Cancer Res. 2015, 75, 5235-5247. [CrossRef]

112. Remon, J.; Passiglia, F.; Ahn, M.J.; Barlesi, F.; Forde, P.M.; Garon, E.B.; Gettinger, S.; Goldberg, S.B.; Herbst, R.S.; Horn, L.; et al. Immune checkpoint inhibitors in thoracic malignancies: Review of the existing evidence by an IASLC expert panel and recommendations. J. Thorac. Oncol. 2020, 15, 914-947. [CrossRef] 
113. Ferro, S.; Huber, V.; Rivoltini, L. Mechanisms of tumor immunotherapy, with a focus on thoracic cancers. J. Thorac. Dis. 2018, 10, 4619. [CrossRef]

114. Freeman, G.J.; Long, A.J.; Iwai, Y.; Bourque, K.; Chernova, T.; Nishimura, H.; Fitz, L.J.; Malenkovich, N.; Okazaki, T.; Byrne, M.C.; et al. Engagement of the Pd-1 immunoinhibitory receptor by a Novel B7 family member leads to negative regulation of lymphocyte activation. J. Exp. Med. 2000, 192, 1027. [CrossRef] [PubMed]

115. Gao, Q.; Wang, X.-Y.; Qiu, S.-J.; Yamato, I.; Sho, M.; Nakajima, Y.; Zhou, J.; Li, B.-Z.; Shi, Y.-H.; Xiao, Y.-S.; et al. Overexpression of PD-L1 significantly associates with tumor aggressiveness and postoperative recurrence in human hepatocellular carcinoma. Clin. Cancer Res. 2009, 15, 971-979. [CrossRef]

116. Bristol Myers Squibb-Bristol Myers Squibb Statement on Opdivo (Nivolumab) Small Cell Lung Cancer U.S. Available online: https:/ / news.bms.com/news/details/2020/Bristol-Myers-Squibb-Statement-on-Opdivo-nivolumab-Small-Cell-LungCancer-US-Indication/default.aspx (accessed on 9 August 2021).

117. Perez-Ruiz, E.; Minute, L.; Otano, I.; Alvarez, M.; Ochoa, M.C.; Belsue, V.; de Andrea, C.; Rodriguez-Ruiz, M.E.; Perez-Gracia, J.L.; Marquez-Rodas, I.; et al. Prophylactic TNF blockade uncouples efficacy and toxicity in dual CTLA-4 and PD-1 immunotherapy. Nature 2019, 569, 428-432. [CrossRef]

118. Ferrara, R.; Mezquita, L.; Texier, M.; Lahmar, J.; Audigier-Valette, C.; Tessonnier, L.; Mazieres, J.; Zalcman, G.; Brosseau, S.; Le Moulec, S.; et al. Hyperprogressive disease in patients with advanced non-small cell lung cancer treated with PD-1/PD-L1 inhibitors or with single-agent chemotherapy. JAMA Oncol. 2018, 4, 1543-1552. [CrossRef]

119. Hartley, G.P.; Chow, L.; Ammons, D.T.; Wheat, W.H.; Dow, S.W. Programmed cell death ligand 1 (PD-L1) signaling regulates macrophage proliferation and activation. Cancer Immunol. Res. 2018, 6, 1260-1273. [CrossRef]

120. Hartley, G.; Regan, D.; Guth, A.; Dow, S. Regulation of PD-L1 expression on murine tumor-associated monocytes and macrophages by locally produced TNF- $\alpha$. Cancer Immunol. Immunother. CII 2017, 66, 523. [CrossRef]

121. Jeong, H.; Kim, S.; Hong, B.-J.; Lee, C.-J.; Kim, Y.-E.; Bok, S.; Oh, J.-M.; Gwak, S.-H.; Yoo, M.Y.; Lee, M.S.; et al. Tumor-associated macrophages enhance tumor hypoxia and aerobic glycolysis. Cancer Res. 2019, 79, 795-806. [CrossRef]

122. Westendorf, A.M.; Skibbe, K.; Adamczyk, A.; Buer, J.; Geffers, R.; Hansen, W.; Pastille, E.; Jendrossek, V. Hypoxia enhances immunosuppression by inhibiting CD4+ effector T cell function and promoting treg activity. Cell. Physiol. Biochem. 2017, 41, 1271-1284. [CrossRef]

123. Lim, S.-O.; Li, C.-W.; Xia, W.; Cha, J.-H.; Chan, L.-C.; Wu, Y.; Chang, S.-S.; Lin, W.-C.; Hsu, J.-M.; Hsu, Y.-H.; et al. Deubiquitination and stabilization of PD-L1 by CSN5. Cancer Cell 2016, 30, 925-939. [CrossRef] [PubMed]

124. Bertrand, F.; Montfort, A.; Marcheteau, E.; Imbert, C.; Gilhodes, J.; Filleron, T.; Rochaix, P.; Andrieu-Abadie, N.; Levade, T.; Meyer, N.; et al. TNF $\alpha$ blockade overcomes resistance to anti-PD-1 in experimental melanoma. Nat. Commun. 2017, 8, 1-13. [CrossRef]

125. Landsberg, J.; Kohlmeyer, J.; Renn, M.; Bald, T.; Rogava, M.; Cron, M.; Fatho, M.; Lennerz, V.; Wölfel, T.; Hölzel, M.; et al. Melanomas resist T-cell therapy through inflammation-induced reversible dedifferentiation. Nature 2012, 490, 412-416. [CrossRef] [PubMed]

126. Bertrand, F.; Rochotte, J.; Colacios, C.; Montfort, A.; Tilkin-Mariamé, A.F.; Touriol, C.; Rochaix, P.; Lajoie-Mazenc, I.; AndrieuAbadie, N.; Levade, T.; et al. Blocking tumor necrosis factor $\alpha$ enhances CD8 T-cell-dependent immunity in experimental melanoma. Cancer Res. 2015, 75, 2619-2628. [CrossRef]

127. Bertrand, F.; Colacios, C.; Ségui, B. TNF-R1, an immune checkpoint in melanoma? Genes Cancer 2015, 6, 369. [CrossRef] [PubMed]

128. TNF-Inhibitor as Immune Checkpoint Inhibitor for Advanced MELanoma-TICIMEL-ClinicalTrials.Gov: NCT03293784. Available online: https:/ / clinicaltrials.gov / ct2/show / NCT03293784 (accessed on 9 August 2021).

129. Wilderman, M.J.; Kim, S.; Gillespie, C.T.; Sun, J.; Kapoor, V.; Vachani, A.; Sterman, D.H.; Kaiser, L.R.; Albelda, S.M. Blockade of TNF- $\alpha$ decreases both inflammation and efficacy of intrapulmonary ad.IFN $\beta$ immunotherapy in an orthotopic model of bronchogenic lung cancer. Mol. Ther. 2006, 13, 910-917. [CrossRef]

130. Boutsikou, E.; Domvri, K.; Hardavella, G.; Tsiouda, D.; Zarogoulidis, K.; Kontakiotis, T. Tumour necrosis factor, interferon-gamma and interleukins as predictive markers of antiprogrammed cell-death protein-1 treatment in advanced non-small cell lung cancer: A pragmatic approach in clinical practice. Ther. Adv. Med Oncol. 2018, 10, 1758835918768238. [CrossRef] [PubMed]

131. Trefny, M.P.; Rothschild, S.I.; Uhlenbrock, F.; Rieder, D.; Kasenda, B.; Stanczak, M.A.; Berner, F.; Kashyap, A.S.; Kaiser, M.; Herzig, P.; et al. A variant of a killer cell immunoglobulin-like receptor is associated with resistance to PD-1 blockade in lung cancer. Clin. Cancer Res. 2019, 25, 3026-3034. [CrossRef]

132. Mercogliano, M.F.; Bruni, S.; Mauro, F.; Elizalde, P.V.; Schillaci, R. Harnessing tumor necrosis factor alpha to achieve effective cancer immunotherapy. Cancers 2021, 13, 564. [CrossRef]

133. Sobo-Vujanovic, A.; Vujanovic, L.; DeLeo, A.B.; Concha-Benavente, F.; Ferris, R.L.; Lin, Y.; Vujanovic, N.L. Inhibition of soluble tumor necrosis factor prevents chemically-induced carcinogenesis in mice. Cancer Immunol. Res. 2016, 4, 441. [CrossRef]

134. Vujanovic, L.; Szymkowski, D.E.; Alber, S.; Watkins, S.C.; Vujanovic, N.L.; Butterfield, L.H. Virally infected and matured human dendritic cells activate natural killer cells via cooperative activity of plasma membrane-bound TNF and IL-15. Blood 2010, 116, 575-583. [CrossRef] [PubMed]

135. Shaikh, F.; He, J.; Bhadra, P.; Chen, X.; Siu, S.W.I. TNF receptor type II as an emerging drug target for the treatment of cancer, autoimmune diseases, and graft-versus-host disease: Current Perspectives and in silico search for small molecule binders. Front. Immunol. 2018, 9, 1382. [CrossRef] [PubMed] 
136. Sheng, Y.; Li, F.; Qin, Z. TNF receptor 2 makes tumor necrosis factor a friend of tumors. Front. Immunol. 2018, 9, 1170. [CrossRef] [PubMed]

137. Fischer, R.; Kontermann, R.E.; Pfizenmaier, K. Selective targeting of TNF receptors as a novel therapeutic approach. Front. Cell Dev. Biol. 2020, 8, 401. [CrossRef] [PubMed]

138. Torrey, H.; Butterworth, J.; Mera, T.; Okubo, Y.; Wang, L.; Baum, D.; Defusco, A.; Plager, S.; Warden, S.; Huang, D.; et al. Targeting TNFR2 with antagonistic antibodies inhibits proliferation of ovarian cancer cells and tumor-associated tregs. Sci. Signal. 2017, 10, 462. [CrossRef]

139. Torrey, H.; Kühtreiber, W.M.; Okubo, Y.; Tran, L.; Case, K.; Zheng, H.; Vanamee, E.; Faustman, D.L. A novel TNFR2 agonist antibody expands highly potent regulatory T cells. Sci. Signal. 2020, 13, 661. [CrossRef]

140. Tam, E.M.; Fulton, R.B.; Sampson, J.F.; Muda, M.; Camblin, A.; Richards, J.; Koshkaryev, A.; Tang, J.; Kurella, V.; Jiao, Y.; et al. Antibody-mediated targeting of TNFR2 activates CD8+ T cells in mice and promotes antitumor immunity. Sci. Transl. Med. 2019, 11, 512. [CrossRef] 